\title{
Molecular survey for the presence of tick-borne haemoparasites in dogs and ticks from the Atlantic Forest environment, Rio de Janeiro state, Brazil
}

\section{Pesquisa molecular sobre a presença de hemoparasitos transmitidos por carrapatos em cães e carrapatos presentes no ambiente de Mata Atlântica no Estado do Rio de Janeiro, Brasil}

\author{
Maria Regina Ferreira'*; Aline Moreira de Souza ${ }^{2}$; Sabrina Destri Emmerick \\ Campos $^{3}$; Nathalie Costa da Cunha ${ }^{4}$; Beatriz Teixeira Gomes da Silva ${ }^{5} ;$ Nathalia \\ Xavier da Silva ${ }^{6}$; Nádia Regina Pereira Almosny ${ }^{2}$
}

Highlights:

Haemoparasites were not common in dogs and ticks in the PESET.

Rhipicephalus sanguineus is a tick dispersed throughout the Atlantic Forest area.

Babesia vogeli was detected, by molecular technique, from one dog's blood sample.

\begin{abstract}
Tick-borne diseases have a significant worldwide impact in the veterinary and medical fields. The Serra da Tiririca State Park (PESET) is an Atlantic forest reserve that is home to a wide variety of wild animal species, but is suffering from unauthorised human activities, such as unregulated construction, such as private dwellings and the introduction of domestic pets. The objective of this study is to determine the prevalence of piroplasms and Hepatozoon spp. in dogs and ticks in the Atlantic Forest reserve. Blood samples were taken from 124 asymptomatic canines and 88 Rhipicephalus sanguineus ticks collected from animals inhabiting the PESET. Molecular techniques targeting fragments of the 18s rRNA gene from piroplasms and Hepatozoon spp. were applied to all samples obtained, and one blood sample $(0.81 \%)$ positive for Babesia vogeli was discovered. All dogs tested negative to Hepatozoon spp. and no tick sample showed positive results for either PCR assay. Despite the low frequency of $B$. vogeli infection found in dogs that inhabit the PESET, parasitized dogs could be a source of transmission for new vectors, other dogs and even wild canines that are part of the native fauna of the park.
\end{abstract}

Key words: Babesia vogeli. Rhipicephalus sanguineus. Rainforest biome. Polymerase chain reaction.

\footnotetext{
${ }^{1}$ Discente de Mestrado, Programa de Pós-graduação em Medicina Veterinária, Clínica e Reprodução Animal, Universidade Federal Fluminense, UFF, Niterói, RJ, Brasil. E-mail: mariaregina@id.uff.br

2 Prof $^{\mathrm{as}_{\mathrm{s}}} \mathrm{Dr}^{\mathrm{as}}$, Departamento de Patologia e Clínica Veterinária, UFF, Niterói, RJ, Brasil. E-mail: alinems@id.uff.br; nadiaalmosny@ id.uff.br

3 Pós-Doutoranda, Programa de Pós-Graduação em Medicina Veterinária, Clínica e Reprodução Animal, UFF, Niterói, RJ, Brasil. E-mail: sabrinadec@id.uff.br

4 Prof $^{\mathrm{a}} \mathrm{Dr}^{\mathrm{a}}$, Departamento de Saúde Coletiva Veterinária e Saúde Pública, UFF, Niterói, RJ, Brasil. E-mail: nathalie.cunha@gmail. com

5 M.e, Programa de Pós-Graduação em Medicina Veterinária, Clínica e Reprodução Animal, UFF, Niterói, RJ, Brasil. E-mail: beatriztgs@hotmail.com

6 Discente de Medicina Veterinária, UFF, Niterói, RJ, Brasil. E-mail: nathxavi@gmail.com

Author for correspondence
} 


\title{
Resumo
}

\begin{abstract}
Doenças transmitidas por carrapatos são capazes de causar impacto significativo na medicina humana e veterinária em todo o mundo. O Parque Estadual Serra da Tiririca (PESET) é uma Reserva ambiental de mata atlântica que abriga uma grande variedade de espécies de animais silvestres, porém, vem sofrendo com a ação de atividades humanas não autorizadas, como as construções irregulares e introdução de animais domésticos. O objetivo deste trabalho foi a detecção de piroplasmas e Hepatozoon spp., em cães e carrapatos. Foram coletadas amostras sanguíneas de 124 caninos assintomáticos e de 88 carrapatos Rhipicephalus sanguineus coletados de animais que habitavam o PESET. Técnicas moleculares tendo como alvo fragmentos do gene 18s rRNA de piroplasmas e de Hepatozoon spp. foram empregadas em todas as amostras obtidas, sendo encontrada uma amostra de sangue $(0.81 \%)$ positiva para Babesia vogeli. Todos os cães foram negativos à pesquisa de Hepatozoon spp. e nenhuma amostra de carrapato apresentou resultado positivo para ambos os ensaios de PCR. Apesar da baixa frequência de infecção por $B$. vogeli encontrada nos caninos que habitam o PESET, nós alertamos para a possibilidade de que cães parasitados possam servir de fonte de transmissão para novos vetores, outros cães e até canídeos silvestres, que façam parte da fauna nativa do parque.
\end{abstract}

Palavras-chave: Babesia vogeli. Rhipicephalus sanguineus. Bioma de Mata Atlântica. Reação em cadeia da polimerase.

Dogs are known to be infected with a variety of bacterial and protozoal haemoparasites (including Babesia spp. and Hepatozoon spp.) that are transmitted by arthropod vectors and produce a range of febrile diseases with nonspecific clinical signs, varying from asymptomatic to fatal cases (Bhattacharjee \& Sarmah, 2013). The piroplasmid protozoans Babesia and Rangelia infect cells of dogs and other vertebrate hosts from urban, rural and wild environments worldwide, resulting in haemolytic anaemia, haemoglobinuria and death (Lemos et al., 2017; Sousa et al., 2017).

The Hepatozoon genus includes protozoans that infect dogs around the world; in Brazil, the species found is considered to be $H$. canis (Forlano et al., 2005). Dogs become infected after ingestion of ticks (invertebrate definitive hosts) containing infective oocysts, which often causes mild or inapparent disease (Baneth, Samish, \& Shkap, 2007; Demoner et al., 2013). Traditionally, Rhipicephalus sanguineus (brown dog tick) has been implicated as the main vector not only for Hepatozoon spp. but also other haemoparasites (Baneth et al., 2007).

Serra da Tiririca State Park (PESET) is located in Rio de Janeiro state and includes the Niterói and Maricá municipalities. It is considered a world biosphere reserve composed of Atlantic Forest vegetation that is home to rare and important species exclusive to this region. Despite being a conservation area, several prohibited activities take place, such as the illegal construction of private properties, deforestation and other environmental crimes. The presence of humans in this region, along with the introduction of domestic pets may, in future, affect the wildlife that exists within this delicate ecosystem (Instituto Estadual do Ambien [INEA], 2013).

Due to the ecology of $R$. sanguineus, pathogens transmitted by this tick have a wide geographical distribution and, since these ticks also occur in the indoor environment, where they can feed on humans, and as many haemoparasitic diseases are zoonotic, a greater epidemiological knowledge of tick-borne infections is required in anthropized biomes, where humans and dogs coexist, often in an irregular way. In this context, the aim of our study was to evaluate, through molecular diagnosis, the presence of piroplasms and Hepatozoon spp. in dogs and their ticks inhabiting the PESET between April 2015 and November 2016. This study was approved by the Committee on Ethics in Animal Use (CEUA) of Federal Fluminense University (UFF), Niterói, 
Rio de Janeiro, Brazil, under project number 1020, 2018. The dogs evaluated were part of a surgical sterilization project, coordinated by UFF School of Veterinary Medicine. Selection criteria were based on the absence of clinical signs, which is important, since asymptomatic animals help maintain the transmission cycle of these haemoparasites.

Samples were collected from dogs that were living unconstrained in the PESET and surrounding areas. Blood samples were collected by venipuncture from jugular or cephalic veins and transferred to tubes containing ethylenediamine tetra acetic acid (EDTA), transported under refrigeration $\left(4{ }^{\circ} \mathrm{C}\right)$ and stored at $-20{ }^{\circ} \mathrm{C}$ for subsequent laboratory processing. At the time of sampling, the dogs were examined for the presence of ticks, which were randomly removed via handpicking and placed inside plastic bottles containing 70\% ethanol at room temperature until identification using a taxonomic key (Barros-Battesti, Arzua, \& Bechara, 2006). Ticks were separated by genus, sex and host.

Genomic DNA was extracted from whole blood using a commercial kit (Illustra blood genomic Prep Mini Spin Kit; GE Healthcare Life Sciences, São Paulo, Brazil) according to the manufacturer's instructions. In order to avoid false negative results, DNA samples were quantified by fluorimetry and standardized to a minimum concentration of $10 \mathrm{ng} /$ $\mu \mathrm{L}$. In addition, DNA was tested for the presence of amplifiable DNA using the primer set GAPDH-F (5' - CCTTCATTGACCTCAACTACAT-3') and

GAPDH-R (5 '-CCAAAGTTGTCATGGATGACC-3'), resulting in amplification of a $399 \mathrm{bp}$ fragment of the gene encoding glyceraldehyde-3phosphatedehydrogenase (GAPDH), which is present in all mammals (Birkenheuer, Levy, \& Breitschwerdt, 2003).

DNA extraction from ticks was performed according to the protocol described by Ferreira and Grattapaglia (1998). The ticks were frozen using liquid nitrogen and then ground using a pestle and mortar. Tick DNA samples were evaluated for concentration and purity using biodrop Touch $^{\mathrm{TM}}$ (Biochrom, United Kingdom) and their concentrations were standardized to $150-200 \mathrm{ng} / \mu \mathrm{L}$ for the PCR reaction.

Conventional polymerase chain reactions were used to test blood and tick DNA for the presence of haemoparasites, using the following protocols. Oligonucleotide primers PIRO-A (5'-AATACCCAATCCTGACACAGGG-3') and PIRO-B (5' 'TTAAATACGAATGCCCCCAAC-3') targeting a fragment of approximately $410 \mathrm{bp}$ of the $18 \mathrm{~S}$ rRNA gene were used to verify positivity for piroplasmids (Solano-Gallego et al., 2008). For the genus Hepatozoon, we used primers HEP-F (5'-ATACATGAGCAAAATCTCAAC-3') and HEP-R (5'-CTTATTATTCCATGCTGCAG-3'), which amplify approximately $666 \mathrm{bp}$ of the $18 \mathrm{~S}$ rRNA gene, according to Inokuma, Okuda, Ohno, Shimoda and Onishi (2002), but with $2.0 \mathrm{mM}$ magnesium chloride and an annealing temperature of $56{ }^{\circ} \mathrm{C}$, chosen after performing respective gradients.

For each reaction, we used positive and negative (ultrapure nuclease-free water) controls. Positive controls consisted of extracted and purified DNA from Babesia vogeli (accession n: GQ214514) and Rangelia vitalii (accession $\mathrm{n}^{\circ}$ : MG028647). The Hepatozoon canis positive control consisted of DNA extracted and purified from blood obtained from a dog naturally infected by $H$. canis, in which diagnostic confirmation was based on visualization of the parasite in blood under a microscope and sequenced following PCR to confirm its identity.

The PCR products underwent electrophoresis on $1.5 \%$ agarose gel stained with GelRed ${ }^{\mathrm{TM}}$ (Uniscience, Miami, EUA) and were visualized under ultraviolet light. Positive samples were excised and purified using a commercial kit (illustra GFX PCR DNA and Gel Band Purification Kit; GE Healthcare Life Sciences, São Paulo, Brazil) following the manufacturer's instructions and sent 
for sequencing on a capillary-type Sanger platform (PDTIS/FIOCRUZ) at Oswaldo Cruz Foundation, Rio de Janeiro, Brazil. Partial sequences were trimmed and assembled in a contig using Molecular Evolutionary Genetic Analysis program (MEGA) version 5 .

In this study, blood samples were obtained from 124 dogs at nine collection points in the PESET, distributed as follows (Figure 1): 1) Várzea das Moças (2254'50.2”S 4259'05.8”W22.913936, -42.984946) 14 dogs; 2) Jardim Fluminense $\quad\left(22^{\circ} 55^{\prime} 28.8^{\prime} \mathrm{S} \quad 4^{\circ} 00^{\prime} 18.1^{\prime \prime} \mathrm{W}\right.$ 22.924662, -43.005040) 12 dogs; 3) Praça do
Mangueirão

(225' 37.3 'S

$43^{\circ} 00^{\prime} 11.2^{\prime \prime} \mathrm{W}-$ 22.927038, -43.003119) 37 dogs; 4) R. Cacilda

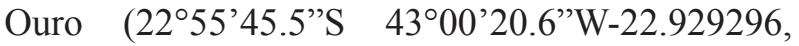
-43.005732) 7 dogs; 5) Engenho do Mato (2256'38.0”S $\quad 43^{\circ} 00^{\prime} 52.1$ 'W-22.943899, -43.014469) 10 dogs; 6) Quilombo do Grotão (2256'27.2”S $\quad 43^{\circ} 00^{\prime} 19.9^{\prime}$ ”W-22.940883, -43.005539) 23 dogs; 7) Caminho de Darwin (2255'44.4"S 42॰59'16.5”'W-22.929010, -42.987911) 8 dogs; 8) Itaipuaçu (22 57'03.0”S 4259'14.6”'W-22.950829, -42.987387) 5 dogs; 9) Morro das Andorinhas (22 58'15.0”S $\left.43^{\circ} 02^{\prime} 36.8^{\prime \prime} \mathrm{W}-22.970843,-43.043548\right) 8$ dogs.

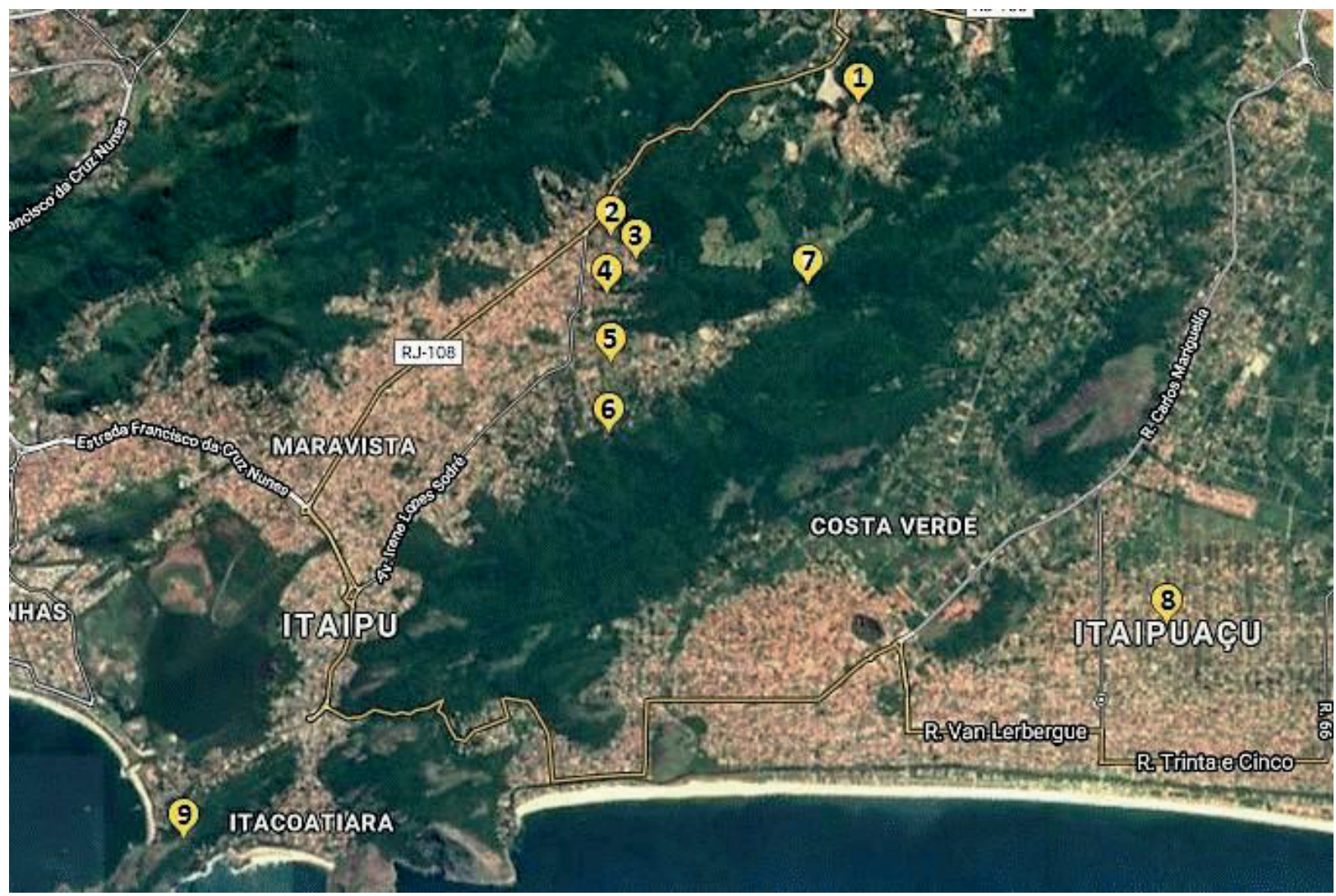

1) Várzea das Moças, 2) Jardim Fluminense, 3) Praça do Mangueirão, 4) R. Cacilda Ouro, 5) Engenho do Mato, 6) Quilombo do Grotão, 7.) Caminho de Darwin, 8) Itaipuaçu, 9) Morro das Andorinhas.

Source: Google Maps.

Figure 1. Aerial image of the region belonging to the Serra da Tiririca State Park, Rio de Janeiro, highlighting the locations at which blood samples from dogs and ticks were collected for this study. 
Only one blood DNA sample $(0.81 \%)$ was positive. The resulting consensus sequence was compared with available sequences from GenBank $^{\mathrm{TM}}$ using the basic local alignment search tool (BLAST), and showed 99\% identity with Babesia vogeli obtained from domestic dogs in Peru (accession no: KY349103) and Paraguay (accession $\mathrm{n}^{\circ}$ : MH100722). The nucleotide sequence reported in this paper was given the accession $n^{\circ}$ : MK208899.

A total of 88 ixodid ticks were collected from 33 dogs, with a mean intensity of 2.67 parasites per animal, all of them identified as $R$. sanguineus, of which $42.04 \%(37 / 88)$ were males, $56.82 \%$ $(50 / 88)$ females and $1.14 \%(1 / 88)$ were larvae. The ticks collected from each region were distributed as follows (Figure 1): 1) Várzea das Moças, 13 samples; 2) Jardim Fluminense, 3 samples; 3) Praça do Mangueirão, 10 samples; 4) R. Cacilda Ouro, 2 samples; 5) Engenho do Mato, 3 samples; 6) Quilombo do Grotão, 43 samples; 7) Caminho de Darwin, 2 samples; 8) Itaipuaçu, 1 sample; 9) Morro das Andorinhas, 11 samples. No DNA extracted from ticks was positive for haemoparasites tested in the present study. Although $R$. sanguineus is the most commonly found tick in urban areas, it can survive in forest areas when similar environmental conditions exist (Araujo et al., 2015). For example, at the study site, many dogs were kept in their homes, mimicking an urban environment that would allow this species to thrive.

The dog with a positive PCR result was a clinically healthy, 2-year-old male living in Quilombo do Grotão (region 6 - Figure 1). The dog presented with fleas and ticks, but had no evidence of recent disease. Additionally, it was able to roam freely, had access to the street, and had been in contact with other dogs, cats and birds in the PESET. The low prevalence of $B$. vogeli infection was expected, especially since a subclinical form of infection may be present when apparently healthy animals are evaluated. The result is comparable with other studies in Brazil; for example, Cruz et al. (2017) examined canines without evidence of clinical disease in Cuiabá, Central-West Brazil and also found only one animal infected by $B$. vogeli. Recently, Temoche et al. (2018) detected B. vogeli in $1.4 \%$ of dogs tested in Peru by conventional PCR. The authors highlighted the fact that animals that did not show any clinical signs compatible with canine babesiosis could be considered "carrier" dogs with chronic infections, and that the low incidence of infected ticks may be associated with the low frequency of animals positive for Babesia spp.

In addition to $B$. vogeli, there is a diversity of piroplasms that can infect domestic dogs, ticks and other susceptible vertebrate hosts. Rangelia vitalii has already been diagnosed in dogs in Southeastern Brazil, and causes severe symptoms, popularly known as Nambiuvú, in reference to the spontaneous bleeding typically observed in affected animals' ears (Lemos et al., 2017). Sousa et al. (2017) found that natural infection among tick populations tended to be low, with a prevalence of $0.7 \%$ of piroplasmid-infected ticks, all of them from Amblyomma genus.

A low frequency of canine hepatozoonosis has been detected in Brazil. Ramos et al. (2010) observed $0.49 \%(1 / 205)$ of dogs infected by $H$. canis in the metropolitan region of Recife using PCR. Research conducted in Brazil indicates Amblyomma ovale as the main vector of this protozoan, with the tick $R$. sanguineus having little or no participation in the transmission of $H$. canis by naturally infected dogs (Forlano et al., 2005; Demoner et al., 2013). Since all the ticks identified in the current study belonged to $R$. sanguineus species, the results for $H$. canis were expected.

In conclusion, haemoparasite infections were not prevalent in dogs and ticks in this study, revealing an epidemiological profile in the area of the PESET that differs from that of urban areas endemic for tick-borne diseases. However, the 
increasing introduction of new domestic animals and low-income populations may change this profile in the future. The detection of just one animal with sufficiently detectable parasitaemia in PCR demonstrates the possibility of transmission to competent vectors and may pose a risk to the rest of the local animal population. Lastly, despite the high sensitivity of PCR assays, we cannot rule out the fact that some animals might have had a low infection rate, less than that required for a positive PCR result. Unfortunately, more sensitive techniques were not available at the time this study was conducted. To confirm these hypotheses, further studies are needed, including larger samples and different diagnostic techniques.

\section{References}

Araujo, A. C., Silveira, J. A. G., Azevedo, S. S., NieriBastos, F. A., Ribeiro, M. F. B., Labruna, M. B., \& Horta, M. C. (2015). Babesia canis vogeli infection in dogs and ticks in the semiarid region of Pernambuco, Brazil. Pesquisa Veterinária Brasileira, 35(5), 456461. doi: 10.1590/S0100-736X2015000500012

Baneth, G., Samish, M., \& Shkap, V. (2007). Life cycle of Hepatozoon canis (Apicomplexa: Adeleorina: Hepatozoidae) in the tick Rhipicephalus sanguineus and domestic dog (Canis familiaris). Journal of Parasitology, 93(2), 283-299. doi: 10.1645/GE494R.1

Barros-Battesti, D. M., Arzua, M., \& Bechara, G. H. (2006). Carrapatos de importância médicoveterinária da região neotropical: um guia ilustrado para identificação de espécies. São Paulo: Ed. Vox/ CTTD-3/Butantan.

Bhattacharjee, K., \& Sarmah, P. C. (2013). Prevalence of haemoparasites in pet, working and stray dogs of Assam and North-East India: a hospital based study. Veterinary World, 6(11), 874-878. doi: 10.14202/ vetworld.2013.874-878

Birkenheuer, A. J., Levy, M. G., Breitschwerdt, E. B. (2003). Development and evaluation of a seminested PCR for detection and differentiation of Babesia gibsoni (Asian genotype) and B. canis DNA in canine blood samples. Journal of Clinical Microbiology, American Society for Microbiology, 41(9), 41724177. doi: 10.1128/jcm.41.9.4172-4177.2003
Demoner, L. C., Rubini, A. S., Paduan, K. S., Metzger, B., Antunes, J. M. A. P., Martins, T. F.,... O’Dwyer, L. H. (2013). Investigation of tick vectors of Hepatozoon canis in Brazil. Ticks and Tick-borne Diseases, 4(6), 542-546. doi: 10.1016/j.ttbdis.2013.07.006

Cruz, F. A. C. S., Otsubo, A. A. F., Trevisan, Y. P. A., Cruz, T. P. P. S., Almeida, A. B. P F., Mendonça, A. J., ... Souza, V. R. F. (2017). Occurrence of Leishmania chagasi, Trypanosoma cruzi, Babesia canis vogeli, Anaplasma platys, and Ehrlichia canis in canine blood donors. Semina: Ciências Agrárias, 38(1), 295-300. doi: 10.5433/1679-0359.2017

Ferreira, M. E., \& Grattapaglia, D. (1998). Introdução ao uso de marcadores moleculares em análise genética. 2a ed. Brasília: EMBRAPA-Cenargen.

Forlano, M., Scofield, A., Elisei C., Fernandes, K. R., Ewing, S. A., \& Massard, C. L. (2005). Diagnosis of Hepatozoon spp. in Amblyomma ovale and its experimental transmission in domestic dogs in Brazil. Veterinary Parasitology, 134(1-2), 1-7. doi: 10.1016/j.vetpar.2005.05.066

Inokuma, H., Okuda, M., Ohno, K., Shimoda, K., \& Onishi, T. (2002). Analysis of the 18S rRNA gene sequence of a Hepatozoon detected in two Japanese dogs. Veterinary Parasitology, 106(3), 265-71. doi: 10.1016/s0304-4017(02)00065-1

Instituto Estadual do Ambiente. (2013). Governo do Estado inaugura unidade de combate a crimes ambientais na Serra da Tiririca. Rio de Janeiro: Site Oficial. Recuperado de http://www.inea.rj.gov.br/ Portal/Noticias/INEA_ 016237

Lemos, T. D., Toma, H. K., Assad, R. Q., Silva, A. V. C., Bartolomeu, R. G., \& Almosny, N. R. P. (2017). Clinical and hematological evaluation of Rangelia vitalii-naturally infected dogs in southeastern Brazil. Revista Brasileira de Parasitologia Veterinária, 26(3), 307-313. doi: 10.1590/s1984-29612017040

Ramos, R., Ramos, C., Araujo, F., Oliveira, R., Souza, I., Pimentel, D.,... Alves, L. (2010). Molecular survey and genetic characterization of tick-borne pathogens in dogs in metropolitan Recife (north-eastern Brazil). Parasitology Research, 107(5), 1115-1120. doi: 10.1007/s00436-010-1979-7

Solano-Gallego, L., Trotta, M., Carl, B., Carcy, B., Caldin, M., \& Furlanello, T. (2008). Babesia canis canis and Babesia canis vogeli clinic pathological findings and DNA detection by means of PCR-RFLP in blood from Italian dogs suspected of tick-borne disease. Veterinary Parasitology, 157(34), 211-221. doi: 10.1016/j.vetpar.2008.07.024 
Sousa, K. C. M., Fernandes, M. P., Herrera, H. M., Freschi, C. R., Machado, R. Z., \& André, M. R. (2017). Diversity of piroplasmids among wild and domestic mammals and ectoparasites in Pantanal wetland, Brazil. Ticks Tick Borne Disease, 9(2), 245253. doi: 10.1016/j.ttbdis.2017.09.010
Temoche, L. C., Assad, R., Seabra-Junior, E. S., Didonet Lemos, T. D., \& Almosny, N. R. P. (2018). Frequency of Babesia vogeli in domestic dogs in the metropolitan area of Piura, Peru. Acta Veterinaria Brno, 87(3), 255-260. doi: 10.2754/avb201887030255 
